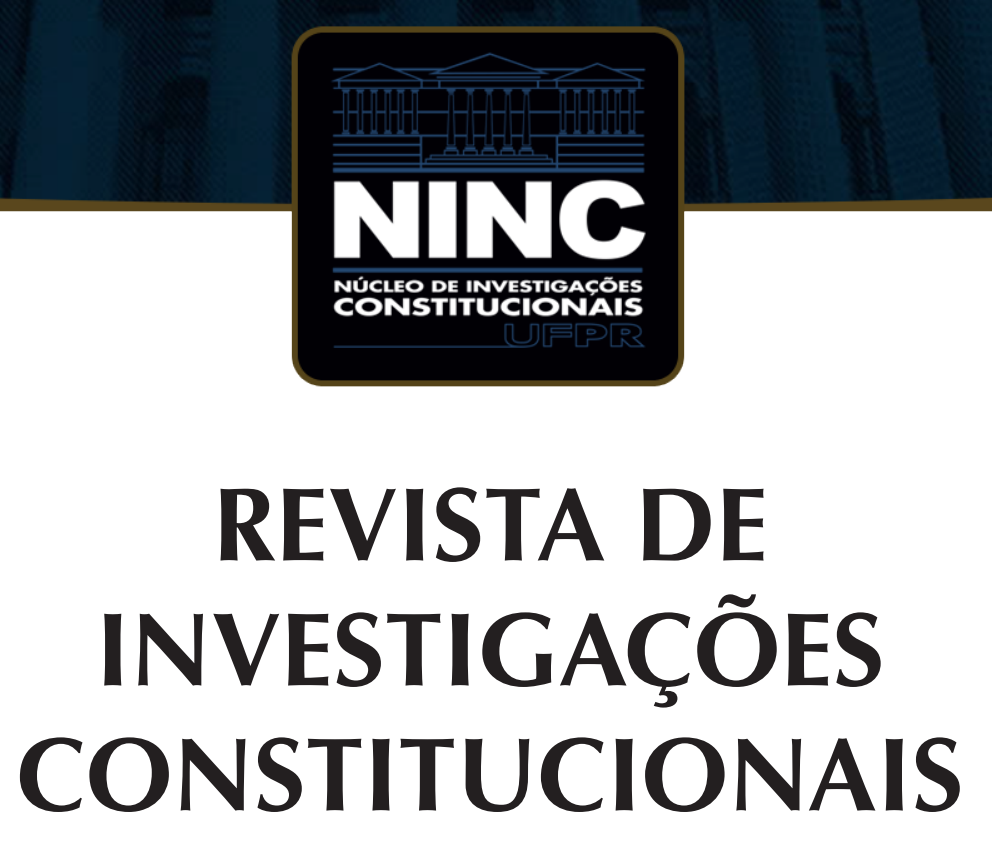

JOURNAL OF CONSTITUTIONAL RESEARCH

vol. 5 | n. 3 | setembro/dezembro 2018 | ISSN 2359-5639 | Periodicidade quadrimestral Curitiba | Núcleo de Investigações Constitucionais da UFPR | www.ninc.com.br 


\section{Constitutional amendments and constitutional core values: the Brazilian case in a comparative perspective}

\section{Emendas constitucionais e valores constitucionais fundamentais: o caso brasileiro em uma perspectiva comparativa}

\section{VALENTINA RITA SCOTTI}

Koç University (Turkey) vscotti@ku.edu.tr

https://orcid.org/0000-0002-2733-476X

Recebido/Received: 13.08 .2018 / August $13^{\text {th }}, 2018$

Aprovado/Approved: 25.08.2018 / August 25 $5^{\text {th }}, 2018$

\section{Abstract}

The debate over the exercise of primary and secondary constituent power is a long-lasting one and is grounded on positions diverging according to the interpretation of constitutionalism and democracy, and to the conception of constitution's flexibility. In order to safeguard the sacrality of the fundamental Charter at the same time ensuring its flexibility, framers, moreover after WWII, entrenched therein both specific procedures for the exercise of the secondary constituent power and clauses for the protection of constitutional fundamentals. After the exhaustion of the primary constituent power, a relevant role has been played by Supreme Courts, which ensured the enforceability of the abovementioned clauses and procedures, and, in some cases, inferred them in the lack of explicit constitutional provisions. The Brazilian Supremo Tribunal Federal (STF) is among those Courts which had to infer their competence in reviewing constitutional amendments from the unamendability clauses
Abstract

O debate sobre o exercício do poder constituinte originário e derivado é duradouro e se baseia em posições divergentes de acordo com a interpretação do constitucionalismo e da democracia, e com a concepção da flexibilidade da Constituição. A fim de salvaguardar a sacralidade da Carta fundamental, assegurando ao mesmo tempo a sua flexibilidade, os seus fundadores, principalmente após a Segunda Guerra Mundial, incluíram procedimentos específicos para o exercício do poder constituinte derivado e cláusulas sobre a proteção dos valores constitucionais fundamentais. Após o esgotamento do poder constituinte originário, uma função relevante foi desempenhada pelos Supremos Tribunais, o que garantiu a aplicabilidade das cláusulas e procedimentos acima mencionados, e em alguns casos identificou-os diante da falta de disposições constitucionais explícitas. O Supremo Tribunal Federal brasileiro (STF) está entre os tribunais que tiveram que inferir sua competência de controlar a constitucionalidade de emendas constitucionais a

Como citar esse artigo/How to cite this article: SCOTTI, Valentina Rita. Constitutional amendments and constitutional core values: the Brazilian case in a comparative perspective. Revista de Investigações Constitucionais, Curitiba, vol. 5, n. 3, p. 59-76, set./ dez. 2018. DOI: 10.5380/rinc.v5i3.60979.

"Post-doctoral fellow in Comparative Public Law at Koç University School of Law (Istanbul, Turkey). PhD at the University of Siena (Siena, Italy). E-mail: vscotti@ku.edu.tr. 
entrenched in the Charter. The analysis, in a comparative perspective, of the STF's activism is the focus of this article.

Keywords: constitutional amendments; constitutional core values; Supreme Federal Court; power of judicial review; judicial activism. partir das cláusulas pétreas consagradas na Constituição. A análise do ativismo do STF numa perspectiva comparativa é o âmago deste artigo.

Palavras-chave: emendas constitucionais; valores constitucionais fundamentais; Supremo Tribunal Federal; controle judicial de constitucionalidade; ativismo judicial.

\section{CONTENTS}

1. Constitutional amendments, unamendability clauses and constitutional core values; 2 . Judicial activisms and constitutional unamendability: a comparative perspective; 3 . The uncertain unamendability of 1988 Brazilian Constitution; 3.1 Unamendability in the interpretation of the Supremo Tribunal Federal;

4. Concluding remarks; 5 . References.

\section{CONSTITUTIONAL AMENDMENTS, UNAMENDABILITY CLAU- SES AND CONSTITUTIONAL CORE VALUES}

The debate over the exercise of primary and secondary constituent power ${ }^{1}$ is a long-lasting one and is grounded on different interpretations of constitutionalism and democracy. The sacrality - and consequent unamendability - of the constitutional Charter John Locke entrenched in 1660 Carolina's Constitution opposes to Edmund Burke's conception that the lack of tools for ensuring flexibility endangers the possibility of preserving the Constitution. In a nutshell, building on Burke, if no rules for modifications are provided, then the whole text can be legally modified through the ordinary legislative procedure. This has been the case, i.e., of the 1848 Italian Albertine Statute, defined perpetual and irrevocable in the Preamble. In name of such a rigidity the progressive evolution toward parliamentarianism, able to subject the Executive to the control of the Parliament and not of the King, was rejected in theory by conservationists ${ }^{2}$ and in practice when the King literally interpreted its power to 'appoint and revoke his ministers' (art. 65) and appointed Mussolini as Prime Minister. Nevertheless, the lack of amending procedure allowed henceforth Fascism to change the institutional structure as well as the bill of rights through the ordinary legislation formally respecting the legality. ${ }^{3}$

In order to allow for constitutional 'maintenance', clauses on flexibility have been therefore progressively introduced in Constitutions, moreover since the end of

\footnotetext{
${ }^{1}$ This distinction was elaborated at first in SIEYES, E. J. Qu'est-ce que le Tiers état?. Paris: Boucher, 2002, distinguishing between pouvoir constituant (constituent power) and pouvoir constitué (constituted power).

${ }^{2}$ SONNINO, Sidney. Torniamo allo Statuto. Nuova Antologia, 151, p. 9-28, 1897.

${ }^{3}$ See BIN, Roberto. Rigidità della Costituzione. Flessibilità degli intellettuali. In: CORTESE, Fulvio (Coord.), Liberare e federare: I'eredità intellettuale di Silvio Trentin. Firenze: Firenze University Press, 2016, p. 25-36, p. 29.
} 
WWII, through the definition of specific procedures for the exercise of the secondary constituent power. The complexity of these procedures can greatly vary according to the required majorities, quora and time delays, but they generally aim at ensuring that fluctuant majorities cannot drastically modify the Constitution though safeguarding a certain degree of flexibility for constitutional maintenance. ${ }^{4}$

Furthermore, through these procedures constitutional identity can be reinterpreted $^{5}$ without recurring to the exercise of the primary constituent power, by its own nature extra legem. ${ }^{6}$ In order to control this reinterpretation, however, in some constituent experiences framers have vaguely declared the unamendability of 'spirit' of the Constitution. A choice still allowing for great margins of interpretation because 'the spirit of the constitution is, in fact, unlikely to be encapsulated in single words [...]. Rather than requiring a predetermined meaning, the 'spirit' of the Constitution admits shifts of meaning.7 A reference to the 'spirit' can be found, for instance, in art. 152 of the 1992 Constitution of Estonia, recognizing to the Supreme Court the power to annul 'any law or other legislation that is in conflict with the provisions and spirit of the Constitution'. Similarly, art. 116 of the 1990 Constitution of Nepal stated the impossibility to introduce amendments violating the 'spirit of the Preamble'. The vagueness and multifaceted meaning of the latter allowed the Supreme Court to enforce its own interpretation of such a spirit and 'legally put down any rebellion against judicial authority'. In other constituent experiences, instead, framers identified constitutional identity and preserved it through clauses pinpointing those sacred - and therefore unamendab$\mathrm{le}^{9}$ through the exercise of the secondary constituent power - provisions and/or concepts representing the constitutional core values. This is the case, i.e., of the 1948 Italian

\footnotetext{
${ }^{4}$ On the different procedures for constitutional amendments and on their consequences on constitution's flexibility, see ROZNAI, Yaniv. Amendment Power, Constituent Power and Popular Sovereignty. Linking Unamendability and Amendment Procedures. In: ALBERT Richard; CONTIADES Xenophon; FOTIADOU Alkmene (Coord.). The Foundations and Traditions of Constitutional Amendment. Oxford: Hart, 2017. p. 37. As Richard Albert underlines, there can be also countries providing nuanced procedures according to the relevance of the provisions to be amended (ALBERT, Richard. Introduction. The State of the Art in Constitutional Amendment. In: ALBERT, Richard; CONTIADES Xenophon; FOTIADOU Alkmene (Coord.). The Foundations and Traditions of Constitutional Amendment. Oxford: Hart, 2017. p. 9).

${ }^{5}$ On this point see ROZNAI, Yaniv. Unamendability and the Genetic Code of the Constitution. New York University Public Law and Legal Theory Working Papers, New York, Paper 514, 2015. p. 26; DIXON, Rosalind. Amending Constitutional Identity. Cardozo Law Review, vol. 33, p. 1847, 2011-2012; ROSENFELD, Michel. The Identity of the Constitutional Subject: Selfhood, Citizenship, Culture, and Community, London: Routledge, 2010.

${ }^{6}$ See KAY, Richard S. Constituent Authority. American Journal of Comparative Law, vol. 59, p. 715, 2011.

${ }^{7}$ See PINELLI, Cesare. The Concept and Practice of Judicial Activism in the Experience of Some Western Constitutional Democracies. Juridica International, vol. XIII, p. 32, 2007.

${ }^{8}$ STITH, Richard. Unconstitutional Constitutional Amendments: The Extraordinary Power of Nepal's Supreme Court. American University International Law Review, vol. 11, n. 1, p. 47-77, 1996.

${ }^{9}$ The effects of entrenching unamendable provisions have been highlighted in ALBERT, Richard. Constitutional Handcuffs. Arizona State Law Journal, vol. 42, n. 3, p. 663, 2010, underscoring their preservative, transformational or reconciliatory role. A further elaboration on these characteristics is proposed in ROZNAI, Yaniv.
} 
Constitution, prohibiting the amendment of the republican form of government (art. 139). Finally, in some countries Supreme Courts have inferred from the Charter implicit limits to constitutional amending power and have assigned to themselves the power of controlling the compliance with them. The most noteworthy and renowned of such Court is the Supreme Court of India, whose experience is discussed below.

Such a power of judicial review of constitutional amendments raises thorny issues moreover given an increasing judicial activism in the interpretation of the (explicit or implicit) criteria for assessing the constitutional amendments' unconstitutionality. ${ }^{10}$ First, the classical counter-majoritarian objection, ${ }^{11}$ roughly based on the unlimited supremacy of the Parliament in name of the respects of the principles of democracy and of people's sovereignty, contests the possibility to vest a non-elected institution with the power to control the will of the (elected) representatives of the people. Conversely, it has been argued that some limits should be imposed for the preservation of the constitutional order; as Cappelletti puts it, 'Constitutions express the positivization' of higher values; judicial review is the method for rendering such values effective'.12 Second, it can be questioned whether this non-elected institution has to exert it only on the formal and procedural aspects or may substantively intervene in investigating the content of constitutional amendments. It is a relevant issue, given the cases of constitutional amendments infringing the core values of the Charter, ${ }^{13}$ and/or representing a constitutional dismemberment, ${ }^{14}$ although they formally respect the rules and procedures.

These issues animated a vivid debate also in Brazil. Here, in the framework of a lengthy and detailed Charter providing also a complex system of judicial review of legislation, the Brazilian Supremo Tribunal Federal (Federal Supreme Court, henceforth also STF) showed its, with regard to activism in the interpretation of the clausulas petreas (petrous clauses) preserving several constitutional features from amending power.

Unamendability and the Genetic Code of the Constitution. New York University Public Law and Legal Theory Working Papers, New York, Paper 514, 2015.

${ }^{10}$ On this point, see GÖZLER, Kemal. Judicial Review of Constitutional Amendments: A comparative study. Istanbul: Ekin, 2008.

${ }^{11}$ The counter-majoritarian argument has allowed the development of a vast literature. Here, it would suffice to mention the seminal work of BICKEL, Alexander. The Least Dangerous branch. The Supreme Court at the bar of politics. New Haven: Yale University Press, 1962.

${ }^{12}$ As CAPPELLETTI, Mauro. The judicial review in the contemporary world. Indianapolis: Bobbs-Merrill, 1971, p. $x$.

${ }^{13}$ BARAK, Ahron. Unconstitutional Constitutional Amendments. Israel Law Review, vol. 44, n. 3, p. 321-341, 2011; ROSNAI, Yaniv. Unamendable Constitutional Amendments. The Limits of Amendment Powers. New York: Oxford University Press, 2017; ORAN, Doyle. Constraints in Constitutional Amendment Power. In: ALBERT Richard; CONTIADES Xenophon; FOTIADOU Alkmene (Coord.). The Foundations and Traditions of Constitutional Amendment. Oxford: Hart, 2017. p. 74-81.

${ }^{14}$ ALBERT, Richard. Constitutional Dismemberment. Boston College Law School - Legal Studies Research Paper, Boston, Paper 424. 2016. 
In this article, therefore, the case of the STF is compared with other Courts' judicial activism for the protection of constitutional core values.

\section{JUDICIAL ACTIVISM AND CONSTITUTIONAL UNAMENDABILI- TY: A COMPARATIVE PERSPECTIVE}

When interpreting provisions or the intent of Charter's authors 'the more a judge feels himself free, in such circumstance, to give the text further meaning, the more he is considered 'activist.'.15 Activist courts may therefore de facto amend the Constitution, somehow challenging the constituent power of framers, by radically changing the literal interpretation of provisions. ${ }^{16}$ The Canadian doctrine of the Constitution as a living tree enhancing the interpretation of the protection of rights far beyond the literal meaning of constitutional provisions ${ }^{17}$ is a good example of such a judicial freedom.

Furthermore, in those legal systems explicitly providing it, Courts may also challenge the secondary constituent power by extensively interpreting their power of judicial review of constitutional amendments. In Turkey, for instance, in spite of the content of art. 148 of 1982 Constitution assigning to the Constitutional Court the power to control constitutional amendments only with regard to the respect of amending procedures, a substantive check has been operated when judges behaved constitutional core values in danger. Indeed, in $2008^{18}$ the Court has used its power to strike down an amendment to art. 10 and 42, which would have enabled the wearing of headscarves in universities, on the grounds that it infringed the unamendable principle of the secular state. ${ }^{19}$

With regard to the challenges to secondary constituent power, as said before, the Supreme Court of the Union of India is the one which proved the greatest judicial activism, as it not only self-recognized the power of judicial review of constitutional amendments, but used it to wage war against the Executive's interpretation of the

\footnotetext{
${ }^{15}$ See PINELLI, Cesare. The concept and practice of judicial activism in the experience of some western constitutional democracies. Juridica International, vol. 13, p. 31, 2007.

${ }^{16}$ This however does not make irrelevant the provision of the mentioned procedures for constitutional amendments, as they safeguard the adherence to the rule of law and to the constitutional transparency. See DIXON, Rosalind. Constitutional Amendment Rules. A Comparative Perspective. Cheltenham: Elgar, 2011, p. 98.

${ }^{17}$ This doctrine was used for the first time ever in the famous 1929'Person's case', when the Privy Council, at the time Court of last resort for Canada, recognized women's right to be appointed at the Senate on the ground that, in spite of a clear mention of women as qualified persons, the provision had to be progressively interpreted in order to include also women. Since then, the doctrine has been diffusely used in Canadian jurisprudence although contrasted by the originalist point of view. On this debate, see: MILLER, Bradley W. Beguiled by Metaphors: The "Living Tree" and Originalist Constitutional Interpretation in Canada. Canadian Journal of Law \& Jurisprudence, vol. 22, n. 2, p. 331-354, 2009.

${ }^{18}$ See Constitutional Court of Turkey, 5 June 2008, n. 2008/116, Resmi Gazete 27032 (Oct. 22, 2008).

${ }^{19}$ According to art. 4 of 1982 Turkish Constitution, art. 1 to 3, protecting a number of principles such as the rule of law, Ataturk's nationalism, secularism, state integrity and republicanism, are unamendable.
} 
directive principles entrenched in the 1949 Union's Constitution. At the beginning, the Court used its power of judicial review of legislation to strike down the laws for land expropriation enacted at the end of the '60s; notably, in the 1967 Golak Nath decision, ${ }^{20}$ supporting land owners' claims against the violation of their property rights, the Court enunciated that the legislative power is bound to the respect of constitutional core principles, which include property rights. Then, when Indira Gandhi's government (elected in 1971) pushed the Parliament to pass constitutional amendments entrenching nationalization and land redistribution in the Charter, the Supreme Court issued the Kesavananda Bharati decision. ${ }^{21}$ In this decision, the Court made two revolutionary interpretations of the Constitution: first, it inferred from the power of judicial review of legislation provided in the Charter an implicit power to review also constitutional amendments; second, it affirmed the existence of a 'basic structure of the Constitution' constitutional amendments, although duly passed by the legislature, cannot infringe or alter. ${ }^{22}$ Finally, when the Parliament passed another constitutional amendment which would have attributed itself an unlimited amending power, the Court issued the $\mathrm{Mi}$ nerva Mills decision ${ }^{23}$ clarifying that the amending power cannot infringe the identity of the existing Constitution. Since then, several other Courts adopted an approach to constitutional amendments based on the 'basic structure doctrine' in order to state the existence of implicit limits. ${ }^{24}$

In a global comparison, this approach to constitutional amending power is counterbalanced by Courts having adopted a strong judicial restraint in compliance with a rigid respect of the principle of parliamentary supremacy. A quite renowned example of judicial restraint is the 1962 decision of the French Conseil Constitutionnel over the amendments passed with a popular referendum on the election of the President of the Republic. ${ }^{25}$ Acting as the Montesquieu's bouche de la loi, the Conseil declared itself bound by people's sovereignty and refused to check the constitutionality of a constitutional

\footnotetext{
${ }^{20}$ Golak Nath v. State of Punjab, 19672 SCR 762.

${ }^{21}$ Kesavananda Bharati v. State of Kerala, 19734 SCC 225.

${ }^{22}$ In Kesavananda the basic structure was defined as to include the supremacy of the Constitution, the republican and democratic form of government, the secular character of the State, the separation of power principle, the federative nature of the state. Nevertheless, this is not a closed list, and the Supreme Court of India has added (or removed) some elements from time to time. For an account of this evolution, see MEHTA, Pratap Bhanu. The inner conflict of constitutionalism. Judicial review and the 'basic structure'. In: HASAN, Zoya; SRIDHARAN, Eswaran. (Coord.) Indian's living constitution: Ideas, practices, controversies. London: Anthem Press, 2005. p. 179-206.

${ }^{23}$ Minerva Mills v. Union of India, 1 SCR 206 [1981].

${ }^{24}$ For some examples, see COLÒN-RIOS, Joel. Beyond parliamentary sovereignty and judicial supremacy: the doctrine of implicit limits to constitutional reform in Latin America. Victoria University of Wellington Law Review, vol. 44, p. 521-534, 2013; MOHALLEM, Michael F. Immutable Clauses and Judicial Review in India, Brazil and South Africa. Expanding Constitutional Courts' Authority. The International Journal of Human Rights, vol. 15, n. 5, p. 765-766, 2011.

${ }^{25}$ See Conseil Constitutionnel, 62-20 DC, 6 November 1962.
} 
amendment approved by referendum. ${ }^{26}$ A lack of competence confirmed in 2003, when the French people was not even directly involved in the approval of the constitutional amendment. $^{27}$

More nuanced, finally, has been the attitude of the German Federal Constitutional Tribunal. Facing the lack of an explicit recognition of the power of judicial review of constitutional amendments in 1949 German Basic Law, the Tribunal demonstrated a certain activism and self-attributed it in $1951 .{ }^{28}$ Notably, it argued that, because the Basic Law is a logical unity and its provisions cannot be interpreted independently, those amendments infringing the higher law and fundamental principles on which the Charter is based should be deemed as unconstitutional and are therefore null and void. Two years later, ${ }^{29}$ the Tribunal added that constitutional amendments infringing those provisions higher than the Basic Law should be deemed as unconstitutional as well and should be therefore struck down. The parameter for assessing the unconstitutionality of constitutional amendments has varied since then, nevertheless respecting the approach that the power of the Parliament to amend the fundamental Charter can be limited when it infringes constitutional core values. ${ }^{30}$ Nevertheless, the post-war activism, deemed necessary when the protection of the constitutional core values was relevant to hinder possible resurgences of the authoritarian phenomenon, ${ }^{31}$ had been progressively abandoned in favour of a more strict respect of art. 79.3 'eternity clause' providing the explicit unamendability only for art. 1 and 20, respectively protecting human dignity and the principles of the democratic and social federal state and of the rule of law. ${ }^{32}$

The position of Courts briefly summarized here represents the main comparative spectrum in which the STF jurisprudence on constitutional amendment can be analysed.

\footnotetext{
${ }^{26}$ On the role attributed to people's sovereignty in the French context, see DEROSIER, Jean-Philippe. The French People's role in amending the Constitution. In: ALBERT Richard; CONTIADES Xenophon; FOTIADOU Alkmene (Coord.). The Foundations and Traditions of Constitutional Amendment. Oxford: Hart, 2017; and BARANGER, Danis. The Language of eternity. Constitutional review of amending power in France (or the absence thereof). Israel Law Review, vol. 44, p. 389, 2011.

${ }^{27}$ See Conseil Constitutionnel, 2003-469 DC, 26 March 2003.

${ }^{28}$ Südweststaat, 2 BverfGE (1951).

${ }^{29}$ See Article 117, 3 BverfGE (1953).

${ }^{30}$ For the other relevant cases on this topic, see Klass 30 BverfGE (1970), Land Reform I 84 BverfGE (1991), Land Reform II 94 BverfGE (1996), Lisbon Treaty 2 BverfGE (2009).

${ }^{31}$ This point was clearly assessed in BRECHT, Arnold. Federalism and Regionalism in Germany. The Division of Prussia. New York: Oxford University Press, 1945, p. 138.

${ }^{32}$ For a scholarly analysis of this evolution, see PREUSS Ulrich K. The implication of the eternity clauses: the German experience. Israel Law Review, vol. 44, p. 429, 2011.
} 


\section{THE UNCERTAIN UNAMENDABILITY OF 1988 BRAZILIAN CONS- TITUTION}

The possibility to amend 1988 Brazilian Constitution has represented a crucial element since its entry into force, probably for its extreme relevance in the process of consolidation of the Brazilian democracy as well as for the circumstances in which it was drafted. Working to a new Charter after a very long period of authoritarianism ${ }^{33}$ and only thanks to a transition the military in power started in 1974 for still controversial reasons, ${ }^{34}$ the 559 members of the Congress elected on 15 November $1986^{35}$ had to serve both as a unicameral constituent assembly ${ }^{36}$ and as a bicameral ordinary legislature under the pressures to be re-elected and at the same time to provide for a text able to control possible future deviations of the governing bodies. Since the first constituent phases, Congressmen therefore refused to work on a draft already prepared by constitutional law scholars, ${ }^{37}$ willing to safeguard the Assembly's independence in the exercise of the constituent power. In order to ensure an open and democratic process, the civil society was also encouraged in presenting proposals through the mechanism of the popular amendment. ${ }^{38}$

The approval of the Charter 19 months later seemed not to exhaust the exercise of the primary constituent power. Indeed, art. 2 of the Temporary Constitutional Provisions Act (TCA) called for a popular referendum five years after the entry into force of the Constitution to decide between the monarchical and the republican form of government. ${ }^{39}$ Furthermore, art. 3 TCA envisaged the possibility that the Constitution

\footnotetext{
${ }^{33} \mathrm{All}$ along the so-called Old Republic (1891-1930) the country was led by a de facto single party system also providing an elitist suffrage mechanism (only the $3 \%$ of the population was entitled to vote), then followed by a period of subsequent military coups - only briefly interrupted by a democratic period - which lasted until 1985. In a nutshell, before the approval of 1988 Constitution, the country actually experience only 16 years of democracy in the 166 years since its independence from Portugal.

${ }^{34}$ See ROSENN, Keith S. Conflict resolution and constitutionalism. The making of the Brazilian Constitution of 1988. In: MILLER Laurel E., AUCOIN Louis (Coord.). Framing the State in Times of Transition: Case Studies in Constitution Making. Washington, DC: USIP, 2010, p. 435-466.

${ }^{35}$ However, it included a Senate indirectly elected by an Electoral College established in 1982 under the previous authoritarian electoral legislation.

${ }^{36}$ It is worthy to remind that, when acting as constituent framers, the members of the Congress divided in eight thematic commissions, each of them split into three sub-commissions. The final systematization effort was then led by a Commission of 97 members.

${ }^{37} \mathrm{~A}$ limited guidance was however provided by the draft elaborated by the Committee led by the distinguished jurist Afonso Arinos appointed by President Sarney. Although he finally decided not to submit Arinos' draft to the Congress, the ideas it contained flawed in the Constituent Assembly. Furthermore, the Assembly enjoyed of the translations in Portuguese of foreign constitutions.

${ }^{38}$ It requires the signatures of at least 30,000 voters and has to be organized by at least three legally constituted associative entities responsible for the authenticity of the signatures.

${ }^{39}$ The referendum was held on 21 April 1993 and the population decided in favour of the republican form of government (66\% against $10.2 \%)$. Called to decide also on the system of government, people chose for presidentialism (55.4\% against $24.6 \%$ ).
} 
could have been completely revised in 1993 by an absolute majority of Congress in a unicameral session. A possibility that however never materialized both for the opposition of important NGOs and for the emergence of a corruption scandal, nicknamed Budget-gate, meanwhile diverting the attention of Congressmen. ${ }^{40}$

At the end of such a long constituent process, Brazil was endowed with a long and detailed Charter, ${ }^{41}$ constitutionalizing almost every aspect of what was deemed important for the institutional life and for the protection of individual and collective rights and also entrenching directive principles for public policies, on the example of the 1937 Irish Constitution. Finally, due to framers reluctance in vesting with the secondary constituent power only the federal Legislature, art. 60 of the Charter attributes the constitutional amending power to several institutional actors ${ }^{42}$ and defines the procedure for exercising it. ${ }^{43}$ Furthermore, art. 60.4 imposes specific limits to the content of constitutional amendments: 'No proposal of amendment shall be considered which is aimed at abolishing the federative form of the State; the direct, secret, universal and periodic vote; the separation of the Government Powers; individual rights and guarantees.44 These limits have been defined as clausulas petreas (petrous clauses) and, as Rosnai underlines, they are able to stand against the exercise of constitutional amending power but can be obliterated by the exercise of constituent power as 'even rocks cannot withstand the volcanic outburst of the primary constituent power.45

The provision of unamendable clauses is not an innovation in the Brazilian constitutional framework and already 1891 Constitution - enacted after the abolition of the Unitary Monarchy - protected from amending power the republican federal form of government as well as the representation of the states in the Senate (art. 90.4). Since then, similar clauses, inspired to those into force in the USA and in Portugal, were then included in 1934, 1946, and 1967 Constitutions. Nevertheless, scholars have contested the effectiveness and genuinity of these clauses: because authoritarianism was nonetheless established, they have been considered a result of constitutional stickiness; ${ }^{46}$

\footnotetext{
${ }^{40}$ For further details on this, see ROSENN, Keith S. Conflict resolution and constitutionalism. The making of the Brazilian Constitution of 1988. In: MILLER Laurel E., AUCOIN Louis (Coord.) Framing the State in Times of Transition: Case Studies in Constitution Making. Washington, DC: USIP, 2010, p. 435-466, p. 453.

${ }^{41}$ It was composed of 245 articles, plus the 70 articles in the Temporary Constitutional Provisions Act.

${ }^{42}$ It is assigned to one-third of the members of the Chamber of Deputies or of the Federal Senate, to the President of the Republic, and to more than one half of the Legislative Assemblies of the units of the Federation each of them expressing itself by the relative majority of its members.

${ }^{43} \mathrm{~A}$ three-fifth majority and two rounds of deliberations in both the House of Representatives and the Senate, is required. According to the rules of procedure of both Houses, once approved on first reading five sessions must follow before a second reading takes place. Rejected or impaired amendments cannot be subject of another proposal in the same legislative session.

${ }^{44}$ For the full text of the 1988 Brazilian Constitution, see http://english.tse.jus.br/arquivos/federal-constitution.

${ }^{45}$ See ROSNAI, Yaniv. Unconstitutional Constitutional Amendments: The limits pf Amendment Powers. New York: Oxford University Press, 2017, p. 164.
}

${ }^{46}$ VAROL, Ozan O. Constitutional Stickiness. UC Davis Law Review, vol. 49, p. 899, 2016. 
being a 'void' repetition of clauses on unamendability they have been deemed as a 'bricolage', that is a constitutional borrowing from foreign provisions 'at hand'.47

Conversely, although they repeat some of the clauses already entrenched in previous Constitutions, clausolas petreas provide for some innovations. First, the formula protecting the nature of the State does not mention the Republican form of government, but only its federative form. ${ }^{48}$ This lack can be explained by the need of keeping the door opened for an amendment waiting for the results of the mentioned 1993 referendum and the possible complete constitutional revision. Furthermore, and more relevantly, a great innovation was the unamendability concerning 'individual rights and guarantees', completely unheard in the previous Brazilian constitutional history.

For the consequences it has had in engendering STF's activism, it is worthy to summarise the system of judicial review of legislation 1988 Constitution provides. It mixed the incidental and diffuse mechanism, entitling every judge with such a power, with the Kelsenian model of abstract control in the hand of an ad hoc Court, which in the case of Brazil is the Supremo Tribunal Federal and not a Constitutional Court established with this aim. Therefore, STF serves as a court of last resort ${ }^{49}$ in the inter partes decisions of unconstitutionality issued by ordinary judges in cases of recursos extraordinarios, ${ }^{50}$ and it acts also as an ad hoc court in the four direct and abstract actions, having an erga omnes effect, ${ }^{51}$ the Constitution provides. Finally, it should be reminded that, while drafting a so complex discipline of the power of judicial review of legislation - which empowers the STF through numerous tools for adjudicating on the activity (and on the omissions) of the Parliament and of the Government and at the same time undermines its authority subjugating the erga omnes effect of some decision to the will of the Senate - framers also 'forgot' to individuate a body entitled to enforce the protection of the clausulas petreas.

\footnotetext{
${ }^{47}$ ROSNAI, Yaniv. Unamendability and the genetic code of the constitution. New York University Public Law and Legal Theory Working Paper, New York, Paper 514, 2015. p. 24-25.

${ }^{48}$ For a comparison among Brazilian Constitutions, notably with reference to the unamendability clauses, see MAIA, Luciano. The Creation and amending process in the Brazilian Constitution. In: ANDENAS M. (Coord.). The creation and amendment of Constitutional Norms. Cheltenham: BIIC, 2000, p. 54-86.

${ }^{49}$ In a system already lacking of the principle of the binding precedent, the STF's authoritative power in the decisions issued under this capacity is lessened by the Senate of the Congress' competence to evaluate on the possibility to abrogate provisions the STF declared unconstitutional, which however is something the Senate has very rarely done, thus limiting the declarations of unconstitutionality to an inter partes effect.

${ }^{50}$ It is worthy to note that since 2004 these appeals are filtered through the provision that they may be introduced only when the case at hand has a general impact on the national legal system (Constitutional Amendment n. 45, 8 December 2004). On the relevance of this amendment for the evolution of the constitutional control of legislation in Brazil see DIAS TOFFOLI, José Antônio. Democracy in Brazil, The evolving role of the country's Supreme Court. Boston College International and Comparative law Review, vol. 40, 2017. p. 245; ROSENN, Keith S. Judicial Reform in Brazil. Law \& Business Review of the Americas, vol. 19, 1998.

${ }^{51}$ Since the approval of the Law n.11.417, 19 December 2006, the STF may also approve, with a specific majority, a sumula vinculante, providing a specific interpretation with an erga omnes binding effect.
} 


\subsection{Unamendability in the interpretation of the Supremo Tribunal Fe- deral}

Matching the almost yearly enactment of a constitutional amendment with the 'amendment difficulty'52 clausulas petreas should represent can be quite hard without underscoring that the most part of these amendments did not concern the core of the Constitution. As Benvindo highlighted, ${ }^{53}$ some of them may be considered 'awkward in a comparative perspective', such as the one for authorizing municipalities to establish a contribution to finance the public lighting service, ${ }^{54}$ for allocating funds destined to irrigation, ${ }^{55}$ for excluding from the monopoly of the union the exploitation of radioisotopes, ${ }^{56}$ and for introducing the monthly pension for rubber tappers. ${ }^{57}$ Some others, however, have been quite relevant for the system, such as those allowing the re-election for a single subsequent term for presidents, governors and mayors, ${ }^{58}$ and introducing a more restrictive rule for presidents to adopt provisional measures. ${ }^{59}$

The reason of this vast exercise of the constitutional amending power can be traced back to the said wide content of the Charter imposing specific directions to the future policy-making. Therefore, the only way for realizing policies different from those provided in the Constitution is to proceed to constitutional amendments. ${ }^{60}$

In this activity of 'adaptation' of the text to the political programs of the governments the Supremo Tribunal Federal has positioned as a very relevant political actor ${ }^{61}$ since it self-recognized a power of judicial review of constitutional amendments at the beginning of ' 90 s, inferring it from the power of judicial review of legislation (art. 102).

\footnotetext{
${ }^{52}$ GINSBURG, Tom; MELTON, James. Does the Constitutional Amendment Rule Matter at All? Amendment Cultures and the Challenges of Measuring Amendment Difficulty. Coase-Sandor Institute for Law \& Economics, Working Paper No. 682, 2014. p. 5.

${ }^{53}$ See BENVINDO, Juliano Zaiden. The Brazilian Constitutional Amendment Rate: A Culture of Change?, International Journal of Constitutional Law Blog. Available at: <http://www.iconnectblog.com/2016/08/the-brazilian-constitutionalamendment-rate-a-culture-of-change/>. Last accessed: 10 Aug. 2016.

${ }^{54}$ Constitutional Amendment n. 39 (December 19, 2002).

${ }^{55}$ Constitutional Amendment n. 43 (April 15, 2004).

${ }^{56}$ Constitutional Amendment n. 49 (February 8, 2006).

${ }^{57}$ Constitutional Amendment n. 78 (May 14, 2014).

${ }^{58}$ Constitutional Amendment n. 16 (June 4, 1997).

${ }^{59}$ Constitutional Amendment n. 32 (September 11, 2001).

${ }^{60}$ COUTO, Cláudio Gonçalves; RANTES, Rogério Bastos. Constituição, Governo e Democracia no Brasil. Revista Brasileira de Ciências Sociais, vol. 21, n. 61, 2006. A noteworthy case in this regard concerns the constitutional amendments introduced for favouring the free marked. This topic is vastly analysed in MENDES Conrado Hübner. Constitutions and Institutions: Justice, Identity and Reform. Judicial review of constitutional amendments in the Brazilian Supreme Court. Florida Journal of International Law, vol. 17, n. 3, p. 449-461, 2005.

${ }^{61}$ Actually, according to ARANTES, Rogério Bastos. Direito e política: o ministério público e a defesa dos direitos coletivos. Revista Brasileira de Ciências Sociais, vol. 14, p. 83-102, p. 83, 1999 the whole Judiciary plays a very relevant role in the system established in 1988 as re-democratization conceived it both as tool for finally ensuring justice after the military regime and as an arbiter between the society and the powers of the State.
} 
Notably, in a 1991 decision the STF affirmed that, because constitutional amendments are an exercise of the secondary constituent power, they can be the object of an abstract control and, in order to protect the constitutional identity defined by the clauses of unamendability, even of an a posteriori review..$^{62}$ The Supremo Tribunal Federal has also explicitly stated that the clauses on unamendability serve to the scope of preserving the continuity and the identity of the Charter, ${ }^{63}$ which may be altered only through the exercise of the (primary) constituent power. Furthermore, because 'procedures to introduce constitutional changes, are expression of an instituted constituent power, thus limited by nature [...] constitutional changes deriving from a revision are subject to judicial control and scrutiny as regard the petrous clauses'.64 This approach has been constantly confirme$\mathrm{d}^{65}$ also clarifying that 'a constitutional amendment, which is emanated from a derived constituent, when violative of the original constitution, may be declared unconstitutional by the Supreme Court, which is the guardian of the constitution' ${ }^{\prime 6}$

This subordinated relation between constituent and constituted powers has been applied also to the hierarchy between States Constitutions and Federal Constitution and about the amendments to the former, Thus, in the exercise of their constituent power, the units of the federation should strictly conform to the federal Charter; ${ }^{67}$ a rule a fortiori valid for units' constitutional amendments.

A very interesting case about the judicial review of constitutional amendments occurred in 2006, with reference to the amendment, which some scholars defined as an unconstitutional constitutional amendment behaving it infringes the protected constitutional core values, ${ }^{68}$ approved on 16 December 2006 as a reaction to the economic malfunction at the federal level. It introduced a New Tax Regime and modified the content of the Act of Transitional Constitutional Provisions in order to provide since 2017 for a twenty-year limit to Brazilian public expenditures accorded to the yearly variation of the inflation rate, somehow limiting the state commitment in protecting social rights and in ensuring public services - such as i.e. health, education, social assistance and security - to which the Constitution bound the state in Title III. Evidently, the amendment, although approved respecting the provided procedures, clashed with two elements included in the clausulas petreas, namely the federal structure of the state and fundamental rights, at the point that it seems aimed at dismembering constitutional rights

\footnotetext{
${ }^{62}$ See ADIMC 466/91 DF.

${ }^{63}$ ADIN n. 815- 3/ DF, DJU de 10/ 05/ 96.

${ }^{64}$ ADIMC 981-8/600/93 PR, Dec. 93.

${ }^{65}$ See i.e., ADIMC 926/ 1993 and ADIMC 981- 8/ 600/ 93 PR.

${ }^{66} \mathrm{ADIN}$ 939-7 DF.

${ }^{67}$ ADIMC 568-5/600/91 AM, 1991.

${ }^{68}$ See ROZNAI, Yaniv; KREUZ, Letícia Regina Camargo. Conventionality control and Amendment 95/2016: a Brazilian case of unconstitutional constitutional amendment. Revista de Investigações Constitucionais, Curitiba, vol. 5, n. 2, p. 35-56, mai./ago. 2018.
} 
with long-lasting effects on a whole generation and even beyond; 69 the amendment also seems to infringe the welfare state that the Constitution wanted to establish.

The Brazilian doctrine has already debated on the Judiciary's adjudications able to alter the public policies on the budget. Notably, Baracho stated the 'it is reasonable to imagine that the Judicial Branch does not intend to be responsible for the economic difficulties that a judicial decision might produce. [...] It is undoubtedly important to preserve the integrity of the Judicial Branch, but it is also essential to secure the exercise of the fundamental rights, even if for that, in certain circumstances, it is necessary, based on constitutional principles, to stop public policies. ${ }^{\prime 0}$ The STF has confirmed this approach when it declared the unconstitutionality of the presidential veto at art. 55, 2 of the Budget Guidelines Law n. 10.707/2003, which violated the 29/2000 Constitutional amendment establishing a minimum of final resources for founding health services and actions. ${ }^{71}$ On that occasion, the STF recognized its lack of competence in defining public policies at the same time considering a responsibility of the Judiciary to intervene when the Executive or the Legislature fail to respect their incumbencies and risk the efficiency and integrity of the individual and/or collective rights constitutionally granted. Therefore, the Judiciary's, and moreover the STF's, role in the protection of rights and in favour of the Brazilian constitutional identity seems a consolidated given. ${ }^{72}$

\section{CONCLUDING REMARKS}

The STF's activist attitude, however, is still controversial because it not only confirms the power of a non-elected body to control the decision of the representatives of the people, but transforms the Court in a policy-makers, allowing it for opting among the different policies through the approval or refusal of an amendment. It is also controversial because there is no certainty that the interpretation the Court will provide is itself consistent with the Constitution and able to conform to the constitutional identity.

\footnotetext{
${ }^{69}$ ALBERT, Richard. Constitutional Amendment and Dismemberment. Yale Journal of International Law, vol. 43, n. 1, 2018.

${ }^{70}$ See BARACHO JUNIOR, J. A. O. A interpretação dos direitos fundamentais na Suprema Corte dos EUA e no Supremo Tribunal Federal. In: SAMPAIO, José Adércio Leite (Coord). Jurisdição constitucional e direitos fundamentais. Belo Horizonte: Del Rey, 2003. p. 343.

${ }^{71}$ See ADPF 45, DJ 29.04.2004.

${ }^{72} \mathrm{~A}$ suggestion may come from the comparative studies with reference to the South Africa Constitutional Court approach to the realization of social rights, which has constantly pushed the government in adopting programs able to secure them notwithstanding the scarcity of resources. In the literature, see SUNSTEIN, Cass R. Social and Economic Rights? Lessons from South Africa. Public Law and Legal Theory Working Paper, Paper 12, 2001.
} 
Paraphrasing Plato $^{73}$ and Giovenale ${ }^{74}$, there is no one controlling those who have the power to control.

Such an issue is even more relevant when the text to be interpreted has an open texture, as the Brazilian one, attributing to its interpreter the power to fill the empty box framers provided. In these cases 'it cannot be said that judicial decisions preserve its [the Charter's] supremacy. They would preserve, instead, the understanding that the Court has of those open norms. ${ }^{75}$

Although these are valid objections - on which the counter-majoritarian argument and the so-called political constitutionalism ${ }^{76}$ have been built up - in the case of Brazil, and possibly of Latin American countries in general, the role the Judiciary plays in protecting rights enjoys of a huge popular support and it is grounded on the detailed references to individual and group rights as well as to State policies entrenched in the Charter. Even when this entails an adjudication on the allotment of the State budget, therefore, STF's activism confirms the will of Brazilian Judiciary in supporting the transformation of paper rights into real guarantees. As a consequence, however, it has represented a source of tension with political authorities, which have frequently underlined how this activism has penalized the efficiency of the courts. ${ }^{77}$ A rationale on which, for instance, the 2004 Judicial Reform Constitutional Amendment has been approved. It is worthy to note, in the end, that even when intervening on the functioning of the Judiciary, the legislator has safeguarded the power of judicial review of constitutional amendments in spite of some speculations in the Brazilian legal doctrine suggesting the possibility of abolishing it. According to Ferreira Filho, ${ }^{78}$ indeed, clausulas petreas are not themselves unamendable so that, in order to amend the provisions they protect, it

\footnotetext{
${ }^{73}$ PLATO. The Republic, III. p. 13.

${ }^{74}$ GIOVENALE. Satire, VI. p. 48-49.

${ }^{75}$ MENDES Conrado Hübner. Constitutions and Institutions: Justice, Identity and Reform. Judicial review of constitutional amendments in the Brazilian Supreme Court. Florida Journal of International Law, vol. 17, n. 3, p. 449-461, 2005. p. 459.

${ }^{76}$ On political constitutionalism, limiting the role of Courts in the review of legislation and a fortiori of constitutional amendments, see BELLAMY, Richard. Political Constitutionalism. A Republican Defense of the Constitutionality of Democracy. Cambridge: Cambridge University Press, 2007; GOLDONI, Marco. Che cos'è il costituzionalismo politico? Diritto e Questioni Pubbliche, vol. 10, 2010; TUSHNET, Mark. Taking the Constitution away from the Courts. New Jersey: Princeton University Press, 1999; Id, The relation between political constitutionalism and weak-form judicial review. German Law Journal, vol. 14, n. 12, 2013; WALDRON, Jeremy. The Core of the Case against Judicial Review. The Yale Law Journal, vol. 115, p. 1346, 2006. For some thoughts more strictly related to the Brazilian context, see LIMA, Jairo Néia; BEÇAK, Rubens. Emenda Constitucional e Constitucionalismo Político: A Potencial Moderação Das Críticas Ao Controle Judicial De Constitucionalidade. Conpedi Law Review, vol. 2, n. 4, p. 275-296, 2016.

${ }^{77}$ On the functioning of Brazilian Judiciary, moreover with reference to rights' protection, see ROSENN, Keith S. Procedural Protection of Constitutional Rights in Brazil. The American Journal of Comparative Law, vol. 59, n. 4, p. 1009-1050, 2011.

${ }^{78}$ FERREIRA FILHO, Manoel Gonçalves. Significação e alcance das 'clausulas pétreas'. Revista de Direito Administrativo, vol. 220, p. 11-17, 1995.
} 
would suffice to proceed to a double amendment procedure, first amending art. 60 and then the core constitutional values it protects. Actually, this is a minority position in the Brazilian literature, being predominant the idea that unamendable clauses are intrinsically unamendable, although this is not explicitly stated in the Charter; ${ }^{79}$ a position the STF already put forward in 1991 declaring the 'National Congress [...] legally bound by the original constituent power, which has laid down, besides circumstantial entrenchment to reform, an immutable clause, immune to parliamentary revision. ${ }^{\prime 80}$

Looking at the Brazilian experience in a comparative perspective, therefore, a sort of 'basic structure doctrine' entrenched in the clausulas pétreas and protected through the judicial review of constitutional amendments seems well established, as well as the principle according to which the complete alteration of the genetic code of the Constitution $^{81}$ can be realized only through a new exercise of the primary constituent power.

\section{REFERENCES}

ALBERT, Richard. Introduction. The State of the Art in Constitutional Amendment. In: ALBERT, Richard; CONTIADES Xenophon; FOTIADOU Alkmene (Coord.). The Foundations and Traditions of Constitutional Amendment. Oxford: Hart, 2017.

ALBERT, Richard. Constitutional Amendment and Dismemberment. Yale Journal of International Law, vol. 43, n. 1, 2018.

ALBERT, Richard. Constitutional Dismemberment. Boston College Law School - Legal Studies Research Paper, Boston, Paper 424. 2016.

ALBERT, Richard. Constitutional Handcuffs. Arizona State Law Journal, vol. 42, n. 3, 2010.

ALBERT, Richard. The expressive function of constitutional amendment rules. McGill Law Journal, p. 225, 2013.

ARANTES Rogerio Bastos, Direito e política: o ministério público e a defesa dos direitos coletivos. Revista Brasileira de Ciências Sociais, vol. 14, p. 83-102, 1999.

BARACHO JUNIOR, J. A. O. A interpretação dos direitos fundamentais na Suprema Corte dos EUA e no Supremo Tribunal Federal. In: SAMPAIO, José Adércio Leite (Coord). Jurisdição constitucional e direitos fundamentais. Belo Horizonte: Del Rey, 2003.

\footnotetext{
${ }^{79}$ SILVA, Virgílio Afonso da. Ulisses, as sereias e o poder constituinte derivado: sobre a inconstitucionalidade da dupla revisão e da alteração no quórum de 3/5 para aprovação de emendas constitucionais. Revista de Direito Administrativo, vol. 226, p. 11-32, 2011.

${ }^{80}$ ADIN n. 815-3/ DF, DJU de 10/ 05/96. For a general perspective on the possibility of amending provisions on unamendability, see ROZNAI, Yaniv. The Theory and Practice of 'Supra-Constitutional' Limits on Constitutional Amendments. International and Comparative Law Quarterly, vol. 62, p. 557, 2013.

${ }^{81}$ ROZNAI, Yaniv. Unamendability and the Genetic Code of the Constitution. New York University Public Law and Legal Theory Working Papers, New York, Paper 514, 2015.
} 
BARAK, Ahron. Unconstitutional Constitutional Amendments. Israel Law Review. vol. 44, n. 3, p. 321-341, 2011.

BARANGER, Danis. The Language of eternity. Constitutional review of amending power in France (or the absence thereof). Israel Law Review, vol. 44, 2011.

BELLAMY, Richard. Political Constitutionalism. A Republican Defense of the Constitutionality of Democracy. Cambridge: Cambridge University Press, 2007.

BENVINDO, Juliano Zaiden. The Brazilian Constitutional Amendment Rate: A Culture of Change?, International Journal of Constitutional Law Blog. Available at: <http://www.iconnectblog. com/2016/08/the-brazilian-constitutionalamendment-rate-a-culture-of-change/>. Last accessed: 10 Aug. 2016.

BICKEL, Alexander. The Least Dangerous branch. The Supreme Court at the bar of politics. New Haven: Yale University Press, 1962.

BIN, Roberto. Rigidità della Costituzione. Flessibilità degli intellettuali. In: CORTESE, Fulvio (Coord.). Liberare e federare: l'eredità intellettuale di Silvio Trentin. Firenze: Firenze University Press, 2016, p. 25-36.

BRECHT, Arnold. Federalism and Regionalism in Germany. The Division of Prussia. New York: Oxford University Press, 1945.

CAPPELLETTI, Mauro. The judicial review in the contemporary world. Indianapolis: Bobbs-Merrill, 1971.

COLÒN-RIOS, Joel, Beyond parliamentary sovereignty and judicial supremacy: the doctrine of implicit limits to constitutional reform in Latin America. Victoria University of Wellington Law Review, vol. 44, p. 521-534, 2013.

COUTO, Cláudio Gonçalves. RANTES, Rogério Bastos. Constituição, Governo e Democracia no Brasil. Revista Brasileira de Ciências Sociais, vol. 21, n. 61, 2006.

DEROSIER, Jean-Philippe. The French People's role in amending the Constitution. In: ALBERT Richard; CONTIADES Xenophon; FOTIADOU Alkmene (Coord.). The Foundations and Traditions of Constitutional Amendment. Oxford: Hart, 2017.

DIXON, Rosalind. Amending Constitutional Identity. Cardozo Law Review, vol. 33, 2011-2012.

DIXON, Rosalind. Constitutional Amendment Rules. A Comparative Perspective. Cheltenham: Elgar, 2011.

FERREIRA FILHO, Manoel Gonçalves. Significação e alcance das 'clausulas pétreas'. Revista de Direito Administrativo, vol. 220, p. 11-17, 1995.

GINSBURG, Tom; MELTON, James. Does the Constitutional Amendment Rule Matter at All? Amendment Cultures and the Challenges of Measuring Amendment Difficulty. Coase-Sandor Institute for Law \& Economics, Working Paper No. 682, 2014. 
GOLDONI, Marco. Che cos'è il costituzionalismo politico? Diritto e Questioni Pubbliche, vol. 10, 2010.

GÖZLER, Kemal. Judicial Review of Constitutional Amendments. A comparative study, Istanbul: Ekin, 2008.

KAY, Richard S. Constituent Authority. American Journal of Comparative Law, vol. 59, 2011.

LIMA, Jairo Néia; BEÇAK, Rubens. Emenda Constitucional e Constitucionalismo Político: A Potencial Moderação Das Críticas Ao Controle Judicial De Constitucionalidade. Conpedi Law Review, vol. 2, n. 4, p. 275-296, 2016.

MAIA, Luciano. The Creation and amending process in the Brazilian Constitution. In: ANDENAS M. (Coord.), The creation and amendment of Constitutional norms, Chatenham: BIIC, 2000.

MARBURY, William L. Limitations upon the amending power. Harvard Law Review, vol. 33, 1919.

MEHTA, Pratap Bhanu. The inner conflict of constitutionalism. Judicial review and the 'basic structure'. In: HASAN, Zoya; SRIDHARAN, Eswaran. (Coord.), Indian's living constitution: Ideas, practices, controversies. London: Anthem Press, 2005, p. 179-206.

MENDES, Conrado Hübner. Constitutions and Institutions: Justice, Identity and Reform. Judicial review of constitutional amendments in the Brazilian Supreme Court. Florida Journal of International Law, vol. 17, n. 3, p. 449-461, 2005.

MILLER, Bradley W. Beguiled By Metaphors: The "Living Tree" and Originalist Constitutional Interpretation in Canada. Canadian Journal of Law \& Jurisprudence, vol. 22, n. 2, p. 331-354, 2009.

MOHALLEM, Michael F. Immutable Clauses and Judicial Review in India, Brazil and South Africa. Expanding Constitutional Courts' Authority. The International Journal of Human Rights, vol. 15, n. 5, p. 765-766, 2011.

ORAN, Doyle. Constraints in Constitutional Amendment Power. In: ALBERT Richard; CONTIADES Xenophon; FOTIADOU Alkmene (Coord.). The Foundations and Traditions of Constitutional Amendment. Oxford: Hart, 2017. p. 73-95.

PINELLI, Cesare. The Concept and Practice of Judicial Activism in the Experience of Some Western Constitutional Democracies. Juridica International, vol. XIII, 2007.

PREUSS, Ulrich K. The implication of the eternity clauses: the German experience. Israel Law Review, vol. 44, 2011.

ROSENFELD, Michel. The Identity of the Constitutional Subject: Selfhood, Citizenship, Culture, and Community. London: Routledge, 2010.

ROSENN, Keith S. Procedural Protection of Constitutional Rights in Brazil. The American Journal of Comparative Law, vol. 59, n. 4, p. 1009-1050, 2011. 
ROSENN, Keith S. Conflict Resolution and Constitutionalism. The Making of the Brazilian Constitution of 1988. In: MILLER Laurel E., AUCOIN Louis (Coord.), Framing the State in Times of Transition: Case Studies in Constitution Making. Washington, DC: USIP, 2010, p. 435-466.

ROSENN, Keith S. Judicial Reform in Brazil. Law \& Business Review of the Americas, vol. 19, 1998. ROSNAI, Yaniv. Unamendable Constitutional Amendments. The Limits of Amendment Powers. New York: Oxford University Press, 2017.

ROZNAI, Yaniv. Amendment Power, Constituent Power and Popular Sovereignty. Linking Unamendability and Amendment Procedures. In: ALBERT Richard; CONTIADES Xenophon; FOTIADOU Alkmene (Coord.). The Foundations and Traditions of Constitutional Amendment. Oxford: Hart, 2017.

ROZNAI, Yaniv; KREUZ, Letícia Regina Camargo. Conventionality control and Amendment 95/2016: a Brazilian case of unconstitutional constitutional amendment. Revista de Investigações Constitucionais, Curitiba, vol. 5, n. 2, p. 35-56, mai./ago. 2018.

ROZNAI, Yaniv. Unamendability and the Genetic Code of the Constitution. New York University Public Law and Legal Theory Working Papers, New York, Paper 514, 2015.

ROZNAI, Yaniv. The Theory and Practice of 'Supra-Constitutional' Limits on Constitutional Amendments. International and Comparative Law Quarterly, vol. 62, 2013.

SIEYES, E. J. Qu'est-ce que le Tiers état?. Paris: Boucher, 2002.

SILVA, Virgílio Afonso da. Ulisses, as sereias e o poder constituinte derivado: sobre a inconstitucionalidade da dupla revisão e da alteração no quórum de 3/5 para aprovação de emendas constitucionais. Revista de Direito Administrativo, vol. 226, p. 11-32, 2011.

SONNINO, Sidney. Torniamo allo Statuto. Nuova Antologia, 151, p. 9-28, 1897.

STITH, Richard. Unconstitutional Constitutional Amendments: The Extraordinary Power of Nepal's Supreme Court. American University International Law Review, vol. 11, n. 1, p. 47-77, 1996.

SUNSTEIN, Cass R. Social and Economic Rights? Lessons from South Africa. Public Law and Legal Theory Working Paper, Paper 12, 2001.

DIAS TOFFOLI, José Antônio. Democracy in Brazil, The evolving role of the country's Supreme Court. Boston College International and Comparative law Review, vol. 40, 2017.

TUSHNET, Mark. Taking the Constitution away from the Courts. New Jersey: Princeton University Press, 1999.

TUSHNET, Mark. The relation between political constitutionalism and weak-form judicial review. German Law Journal, vol. 14, n. 12, 2013.

VAROL, Ozan O. Constitutional Stickiness. UC Davis Law Review, vol. 49, p. 899, 2016.

WALDRON, Jeremy. The Core of the Case against Judicial Review. The Yale Law Journal, vol. 115, p. $1346,2006$. 